\title{
PERANAN GAYA KEPEMIMPINAN TERHADAP MOTIVASI KERJA DAN KINERJA KARYAWAN PT. JAMSOSTEK (PERSERO) CABANG YOGYAKARTA
}

\author{
Resy Wina Putra \\ Alumni Manajemen Fakultas Ekonomi Universitas Islam Indonesia \\ Suhartini \\ Fakutlas Ekonomi Universitas Islam Indonesia \\ e-mail: 903110101@uii.ac.id
}

\begin{abstract}
This study aims to determine the effect of leadership style is instructive, consultative, participative, and delegative jointly or partially on work motivation and employee performance, determine the effect of motivation on performance as well as determine the effect of motivation as a intervening variable between leadership styles on employee performance PT. Jamsostek (Persero) in Yogyakarta. The population in this study are permanent employees of PT. Jamsostek (Persero) Branch of Yogyakarta is located in Jln. Urip Sumoharjo 106 which are 32 employees. While the sample in this study using a census method for a total sample of 32 employees. Analytical model used in this study is a simple linear regression analysis and multiple linear regression analysis. The results found partial simultaneous leadership style and instructive, consultative, participative, and delegative to the motivation of employees of PT. Social Security Branch of Yogyakarta, There is a positive influence of motivation on the performance of employees of PT. Social Security Branch of Yogyakarta, There is a simultaneous influence of leadership style and a partial instructive, consultative, participative, and delegative on the performance of employees of PT. Social Security Branch of Yogyakarta, and the most influential leadership style is positively instructive to work motivation, whereas the most influential consultative leadership style positively to the performance of employees of PT. Social Security Branch of Yogyakarta.
\end{abstract}

Keywords: leadership style, instructive, consultative, participative, delegative, motivation and employee performance.

\section{LATAR BELAKANG MASALAH}

Sumber daya manusia dalam perusahaan memegang peranan penting. Pemanfaatan sumber daya manusia merupakan kunci keberhasilan dalam pencapaian tujuan perusahaan. Di sisi lain, keberhasilan perusahaan dalam meningkatkan kualitas dan kuantitas tidak lepas dari peran pemimpin. Kepemimpinan merupakan faktor yang sangat penting dalam mendukung prestasi organisasi dan prestasi kerja karyawan.

Prawirosentono (1999) berpendapat bahwa karyawan dapat dikatakan berprestasi dalam pekerjaan jika mereka dapat melaksanakan pekerjaannya dengan baik, artinya mencapai tujuan kerja yang ditetapkan. Peningkatan kinerja karyawan tidak lepas dari acuan atau arahan seorang pemimpin. Sifat-sifat dari pemimpin antara lain sikap teladan, kedewasaan, keluwesan hubungan sosial, cara yang digunakan dan pengetahuan tentang kepemimpinan. Dalam mencapai tujuan perusahaan juga tidak lepas dari keberhasilan kerja karyawan. Para karyawan dalam melaksanakan tugasnya dibarengi dengan motivasi kerja.

Kim (2002) menyatakan bahwa praktek manajemen partisipatif mempunyai pengaruh positif yang substansial terhadap kinerja. Hasil penelitian Shea 
(1999), juga menunjukkan bahwa gaya kepemimpinan memiliki pengaruh pada peningkatan kinerja sepanjang waktu.

Robbins (2006) mendefinisikan motivasi sebagai proses yang ikut menentukan intensitas, arah dan ketekunan individu dalam usaha mencapai sasaran. Berkaitan dengan motivasi, Nawawi (2008) menyatakan bahwa setiap pekerja memerlukan motivasi yang kuat agar bersedia melaksanakan pekerjaannya secara bersemangat, bergairah dan berdedikasi. Motivasi kerja karyawan akan berpengaruh terhadap kinerja karyawan.

\section{Rumusan Masalah}

1. Apakah gaya kepemimpinan instruktif, konsultatif, partisipatif, dan delegatif secara parsial dan simultan berpengaruh terhadap motivasi kerja karyawan PT. Jamsostek (Persero) di Yogyakarta?

2. Apakah gaya kepemimpinan instruktif, konsultatif, partisipatif, dan delegatif secara parsial dan simultan berpengaruh terhadap kinerja karyawan PT. Jamsostek (Persero) di Yogyakarta?

3. Diantara Gaya kepemimpinan instruktif, konsultatif, partisipatif, dan delegatif, variabel manakah yang mempunyai pengaruh paling besar terhadap kinerja karyawan PT. Jamsostek (Persero) di Yogyakarta?

4. Apakah motivasi kerja berpengaruh terhadap kinerja karyawan PT. Jamsostek (Persero) di Yogyakarta?

5. Manakah yang lebih besar pengaruhnya antara pengaruh langsung (gaya kepemimpinan terhadap kinerja) ataukah pengaruh tidak langsung (gaya kepemimpinan terhadap kinerja melalui motivasi kerja)?

\section{KAJIAN PUSTAKA}

Hasil penelitian Wahyuddin dan Djumino (2008) menunjukkan hasil bahwa baik masing-masing atau secara bersama-sama, variabel kepemimpinan, dan motivasi mempunyai pengaruh yang positif terhadap kinerja pegawai. Sedangkan hasil penelitian Purnomo (2002) menjelaskan bahwa kepemimpinan, motivasi dan lingkungan, hanya kepemimpinan yang berpengaruh signifikan terhadap kinerja Pegawai Negeri Sipil pada Dinas Kehutanan dan Perkebunan Kabupaten Jepara. Namun demikian, secara bersamasama variabel-variabel tersebut berpengaruh signifikan. Penelitian yang dilakukan oleh Suranta (2003), Guritno \& Waridin (2005) dan Suharto dan Cahyono (2005) menunjukkan hasil bahwa ada pengaruh signifikan antara persepsi bawahan tentang gaya kepemimpinan terhadap kinerja bawahan.

Penelitian mengenai motivasi sebagai variabel intervening dilakukan oleh Mehta dkk (2003) dengan judul Leadership style, motivation and performance in international marketing channels An empirical investigation of the USA, Finland and Poland. Penelitian dilakukan pada 600 responden pada perusahaan importir Amerika, Finlandia dan Polandia. Hasil penelitian menunjukkan bahwa kepemimpinan partisipatif, kepemimpinan suportif dan kepemimpinan direktif berpengaruh secara signifikan terhadap motivasi di Amerika Serikat. Sedangkan di negara Finlandia hanya kepemimpinan partisipatif saja yang berpengaruh terhadap motivasi. Sementara untuk Polandia gaya kepemimpinan tidak berpengaruh signifikan terhadap motivasi kerja. Hasil juga menunjukkan bahwa motivasi kerja berpengaruh terhadap kinerja baik di Amerika maupun Finlandia, sedangkan di Polandia tidak terjadi pengaruh yang signifikan. Hasil ini memberikan kesimpulan bahwa motivasi merupakan variabel intervening hubungan antara gaya kepemimpinan dengan kinerja karyawan

Pfeffer (1997; dalam Payamta, 2005) berpendapat bahwa konsep kepemimpinan masih merupakan sesuatu yang ambigu. Diagnosis situasi harus dilakukan berkaitan dengan kapan, tuntutan iklim 
organisasi, harapan, kemampuan atasan dan bawahan. Pendekatan situasional menyarankan dua perilaku pemimpin yang efektif yaitu selalu memperhatikan situasi yang dihadapi dan memperlakukan bawahan sesuai dengan kebutuhan masing-masing. Pemimpin penganut pendekatan situasional cenderung berperilaku yang dapat diklasifikasikan menjadi perilaku direktif dan perilaku suportif. Dalam perilaku direktif, pemimpin bersifat memberi pengarahan, perintah, petunjuk yang berorientasi pada tugas. Sedangkan perilaku suportif, pemimpin memberikan dukungan, motivasi, semangat kerja, pertimbangan-pertimbangan manusiawi yang berorientasi pada perbaikan hubungan atasan bawahan.

Selanjutnya kedua perilaku ini dihubungkan dengan tingkat kematangan bawahan. Kematangan bawahan menunjukkan sejauh mana bawahan mempunyai kemampuan dan kemauan melaksanakan tugas dengan baik dengan tanpa diawasi. Hubungan antara kedua jenis perilaku pimpinan dan kematangan bawahan menunjukkan empat jenis gaya kepemimpinan yang efektif untuk situasi tertentu. Ke empat gaya kepemimpinan tersebut adalah sebagai berikut. (1) Gaya Instruktif: pemimpin cenderung memberikan pengarahan (direktif) dan suportif yang rendah. Pemimpin memberikan instruksi disertai pengawasan yang ketat. Gaya ini sesuai untuk menghadapi bawahan yang belum matang, (2). Gaya Konsultatif: pemimpin memberikan direktif dan suportif yang tinggi. Setiap keputusan memperhatikan masukan bawahan yang telah lebih matang, (3) Gaya Partisipatif: pemimpin memberikan suportif tinggi tetapi direktif yang rendah. Pemimpin mengambil keputusan yang memperhatikan masukanmasukan bawahan. Gaya ini sesuai untuk menghadapi bawahan yang sudah agak matang dan (4) Gaya Delegatif: pemimpin memberikan direktif dan suportif yang rendah. Pemimpin menyerahkan pengambilan keputusan dan pertanggungjawaban penuh pada bawahan. Gaya Delegatif hanya cocok untuk menghadapi bawahan yang benar-benar sudah matang.

Handoko (2011) mendefinisikan motivasi sebagai keadaan dalam pribadi seseorang yang mendorong keinginan individu untuk melakukan kegiatankegiatan tertentu guna mencapai tujuan. Menurut Mc Clelland (1961) dalam Suprihanto, dkk, (2003) ada tiga indikator penyebab motivasi gunakan. (1) Kebutuhan prestasi, tercermin pada keinginan seesorang mengambil tugas dimana dia dapat bertanggung jawab secara pribadi atas perbuatan-perbuatannya, dia menentukan tujuan yang wajar dengan memperhitungkan risiko-risikonya, dia ingin mendapatkan umpan balik atas perbuatan-perbuatannya dan dia berusaha melakukan segala sesuatu secara kreatif dan inovatif, (2) Kebutuhan afiliasi, kebutuhan ini ditunjukkan dengan adanya keinginan untuk bersahabat, dimana dia lebih mementingkan aspek-aspek antar pribadi dalam bekerja, dia lebih senang bekerja sama, senang bergaul, dia berusaha mendapatkan persetujuan dari orang lain dan dia akan melaksanakan tugas-tugasnya secara lebih efektif bila bekerja dengan orang-orang lain dalam suasana kerjasama. Tetapi jika seorang atasan minta bantuan bawahan, ini bukan tergolong motivasi afiliasi tetapi tergolong motivasi kekuasaan. (3) Kebutuhan kekuasaan, kebutuhan ini tercermin pada seseorang yang ingin mempunyai pengaruh atas orang-orang lain, dia peka terhadap struktur pengaruh antar pribadi suatu kelompok atau organisasi. Ia akan mencoba menguasai orang lain dengan cara mengatur perilakunya dan membuat orang lain terkesan kepadanya, serta selalu menjaga reputasi dan kedudukannya. 


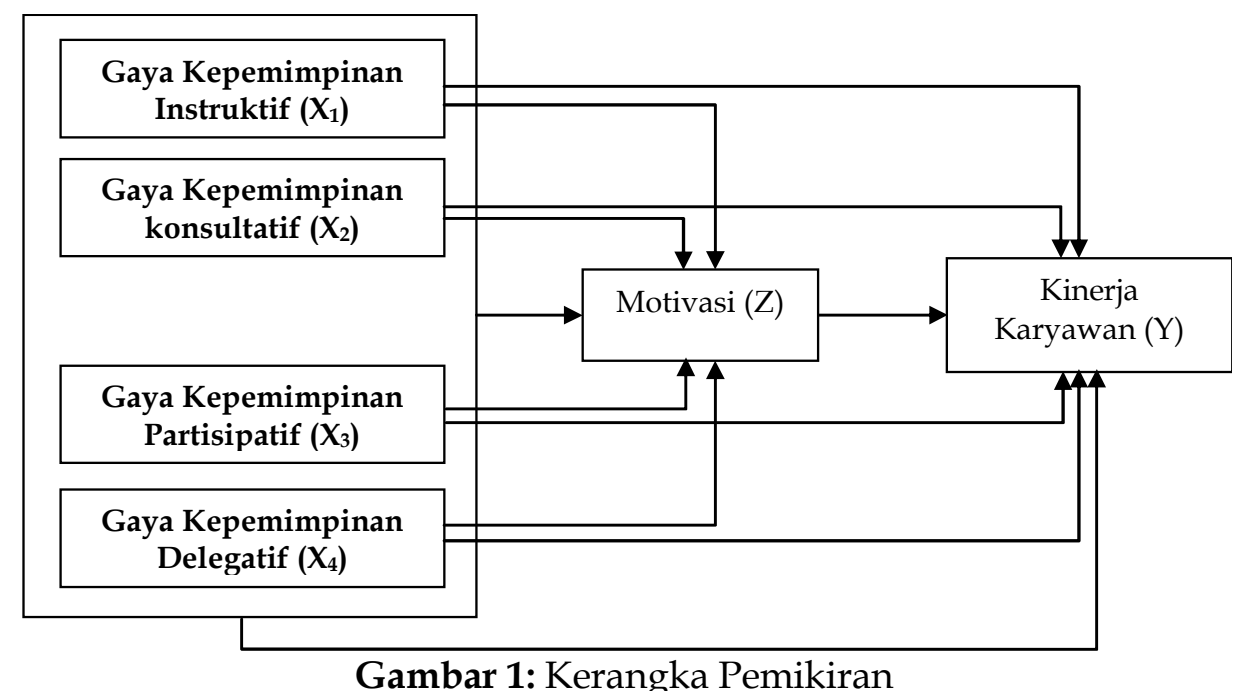

Sedangkan Nawawi (2008) mendefinisikan kinerja adalah hasil pelaksanaan suatu pekerjaan, baik bersifat fisik/material maupun non-fisik/nonmaterial. Prawirosentono (1999) menyatakan bahwa kinerja dipengaruhi oleh motivasi karyawan yang bekerja dalam suatu organisasi. Bila karyawan motivasinya rendah, jangan berharap hasil kerja (kinerjanya) baik. Keberhasilan suatu kinerja didasarkan atas efektivitas dan efisiensi, tanggung jawab, disiplin dan inisiatif. Disini dapat dilihat ada pengaruh antara motivasi dengan kinerja.

\section{Hipotesis}

1. Gaya kepemimpinan instruktif, konsultatif, partisipatif, dan delegatif berpengaruh secara parsial dan simultan terhadap motivasi kerja karyawan PT. Jamsostek (Persero) di Yogyakarta.

2. Gaya kepemimpinan instruktif, konsultatif, partisipatif, dan delegatif berpengaruh secara parsial dan simultan terhadap kinerja karyawan PT. Jamsostek (Persero) di Yogyakarta.

3. Gaya kepemimpinan konsultatif mempunyai pengaruh paling besar terhadap kinerja karyawan PT. Jamsostek (Persero) di Yogyakarta.

4. Motivasi kerja berpengaruh terhadap kinerja karyawan PT. Jamsostek (Persero) di Yogyakarta.
5. Pengaruh langsung (gaya kepemimpinan terhadap kinerja) lebih besar dibandingkan pengaruh tidak langsung (gaya kepemimpinan terhadap kinerja melalui motivasi kerja).

\section{METODE PENELITIAN Populasi dan Sampel}

Populasi dalam penelitian ini adalah karyawan tetap PT. Jamsostek (Persero) Cabang Yogyakarta yang berada di Jln. Urip Sumoharjo No.106 berjumlah 32 orang. Merupakan penelitian populasi, di mana pengambilan sampel dalam penelitian ini menggunakan metode sensus.

\section{Jenis dan Metode Pengumpulan Data}

Jenis data yang dibutuhkan dalam penelitian ini adalah data primer dan sekunder. Data Primer diperoleh langsung dari sumbernya yaitu melalui kuisioner yang diajukan kepada responden dan wawancara. Kuesioner disusun dengan menggunakan skala likert 4 kategori. Sedangkan data sekunder diperoleh melalui bagian personalia PT JAMSOSTEK di Yogyakarta.

\section{Identifikasi Variabel}

Variabel penelitian terdiri dari:(1) variable bebas $(X)$, yaitu gaya kepemimpinan instruktif $\left(X_{1}\right)$, konsultatif $\left(X_{2}\right)$, partisipatif 
$\left(X_{3}\right)$ dan delegatif $\left(X_{4}\right), \quad(2)$ Variabel intervening $(Z)$ yaitu motivasi kerja dan (3) Variabel terikat $(Y)$ adalah Kinerja karyawan

\section{Definisi Operasional Variabel}

Gaya Instruktif $\left(X_{1}\right)$ dimana pemimpin cenderung memberikan pengarahan dan dukungan yang rendah. Indikatornya adalah, (a) pemimpin memberikan pengarahan dengan petunjuk yang jelas dan tegas, (b) pemimpin memberikan intruksi yang spesifik tentang peranan dan tujuan bagi bawahannya, (c) pemimpin sangat tinggi orientasinya pada tugas bawahan, (d) pemimpin pengawasi dengan ketat pelaksanaan tugas bawahan

Gaya Konsultatif $\left(X_{2}\right)$ dimana pemimpin memberikan pengarahan dan dukungan yang tinggi. Indikatornya adalah, (a) pemimpin memberikan petunjuk dan pengarahan kepada bawahan, (b) pemimpin berkonsultasi dengan bawahan dalam pengambilan keputusan, (c) pemimpin membuat komunikasi dua arah dengan para bawahan dan (d) pemimpin tidak pernah memberikan pengendalian kepada bawahannya

Gaya Partisipatif $\left(X_{3}\right)$ dimana pemimpin memberikan dukungan tinggi tetapi pengarahan rendah. Indikatornya adalah, (a) pemimpin selalu mengadakan kerjasama, (b) pemimpin bekerjasama dengan bawahan dalam pengambilan keputusan, (c) pemimpin secara bergantian dengan bawahan dalam pemecahan masalah dan pembuatan keputusan dan (d) Pemimpin memberikan dukungan kepada bawahan dalam pemecahan masalah dan perbuatan

Gaya Delegatif $\left(X_{4}\right)$ dimana pemimpin memberikan pengarahan dan dukungan rendah. Indikatornya adalah, pemimpin memberikan (1) kontrol pelaksanaan dengan memberikan tanggung jawab kepada bawahan, (2) kepercayaan penuh kepada bawahan untuk menyelesaikan tugas tertentu, (3) kepercayaan kepada bawahan agar percaya diri, mandiri dan dapat mengaktualisasikan diri untuk berprestasi, (4) kewenangan kepada bawahan untuk memutuskan bagaimana cara melaksanakan tugas

Motivasi $(Z)$ didefinisikan sebagai keadaan dalam pribadi seseorang yang mendorong keinginan individu untuk melakukan kegiatan tertentu guna mencapai tujuan. Indikatornya adalah, (a) menetapkan target pekerjaan, (b) mencari inovasi cara kerja baru, (c) menyukai pekerjaan dengan resiko yang telah di perhitungkan, (d) menyukai pekerjaan yang menarik dan menantang, (e) ingin mengetahui hasil atas pekerjaan yang telah di selesaikan, (f) menyayangi pekerjaan yang dapat diinteraksi dengan teman sekerja, (g) menjadi anggota perkumpulan, (h) aktifitas dalam pekerjaan membuat senang, (i) bahagia jika berbuat sesuatu yang menyenangkan, (j) suka menolong orang meskipun tidak di minta, $(\mathrm{k})$ ingin orang sejalan dengan kemauannya, (l) menyenangi dan kemajuannya cepat, (m) bekerja keras untuk memperoleh penghargaan, dan (n) menjadi anggota sejumlah organisasi.

Kinerja Karyawan $(Y)$ merupakan hasil kerja yang dapat dicapai seorang sesuai dengan wewenang dan tanggung jawab masing-masing. Indikator: (1) tepat waktu penyerahan laporan keuangan, (2) kualitas pengelolaan keuangan, (3) koreksi, (4) penyelesaian rekonsiliasi, (5) penyerahan laporan keuangan $\mathrm{KBC}$, (6) penyerahan laporan keuangan DPKP, (7) penyerahan laporan transaksi, (8) sarana pendukung, (9) pemenuhan transfer pihak ke3 dan (10) monitoring bunga deposito

\section{Uji Instrumen Penelitian}

Uji instrumen penelitian dilakukan melalui uji validitas dan uji reliabilitas. Uji instrumen penelitian dilakukan pada 32 responden. Hasil uji validitas terhadap 36 butir pernyataan menunjukkan bahwa semua item pertanyaan yang diuji adalah 
valid dengan tingkat signifikansi koefisien korelasi $\leq 0,05$. Hasil uji reliabilitas menunjukkan bahwa semua variabel yang diuji dinyatakan reliabel dengan koefisien alpha antara 0,60 sampai dengan 0,85 .

\section{Metode Analisis}

Metode analisis menggunakan analisis statistik deskriptif dan analisis statistik inferensial: uji $\mathrm{F}$ dan uji $\mathrm{t}$, dengan model regresi linier berganda, Analisis regresi dilakukan secara bertahap. Analisis dan perhitungan menggunakan program SPSS for Windows versi 16 .

\section{HASIL DAN PEMBAHASAN}

Penelitian ini melakukan penyebaran kuesinoer sebanyak 32 orang dan yang kembali dan dapat diolah sebanyak 32 kuesioner (100\%).

\section{Analisis Deskriptif Analisis Deskripsi Karakteristik Responden}

Pada Tabel 1 ditunjukkan bahwa sebagian besar karyawan PT Jamsostek Yogyakarta adalah berpendidikan sarjana S1, berjenis kelamin laki-laki, berusia antara 40-50 tahun dan telah memiliki masa kerja 10-20 tahun. Tingkat pendidikan formal seluruh Karyawan PT. Jamsostek Yogyakarta mayoritas adalah berpendidikan tinggi, hal ini diharapkan akan memberikan kualitas yang maksimal. Tidak dapat dipungkiri, bahwa pendidikan merupakan hal yang penting untuk melakukan tindakan yaitu tindakan untuk melakukan pekerjaan yang menggunakan pengetahuan, keahlian dan kemampuan. Notoadmojo (2003) menyatakan bahwa pengetahuan atau kognitif merupakan domain yang sangat penting untuk terbentuknya tindakan seseorang. Di sisi lain, Popenoe (1977) (dalam Sarwono \& Soeroso (2001)) berpendapat bahwa fungsi pendidikan adalah sosialisasi dan transmisi pengetahuan kultural seperti nilai (value) dan kepercayaan (belief), untuk individu memilih dan belajar peran sosial serta mempertemukan antara bakat (talent) dan kemampuannya (ability) dengan kebutuhan pekerjaan.

Tabel 1: Karakteristik Responden

\begin{tabular}{ccc}
\hline $\begin{array}{c}\text { Tingkat } \\
\text { Pendidikan }\end{array}$ & Frekuensi & Persentase \\
\hline S1 & 16 & $50,0 \%$ \\
D3 & 5 & $15,6 \%$ \\
SMA dan & & \\
Sebelumnya & 11 & $34,4 \%$ \\
Jenis Kelamin & Frekuensi & Persentase \\
Laki-laki & 20 & $62,5 \%$ \\
Perempuan & 12 & $37,5 \%$ \\
Tingkat Umur & Frekuensi & Prosentase \\
<30 tahun & 4 & $12,5 \%$ \\
$30-40$ tahun & 8 & $25,0 \%$ \\
$40-50$ tahun & 17 & $53,1 \%$ \\
$>50$ tahun & 3 & $9,4 \%$ \\
Masa Kerja & Frekuensi & Persentase \\
$<10$ tahun & 7 & $21,9 \%$ \\
10-20 tahun & 11 & $34,4 \%$ \\
20-30 tahun & 10 & $31,3 \%$ \\
$>30$ tahun & 4 & $12,5 \%$ \\
\hline
\end{tabular}

Sumber: Data Primer Yang Diolah Tahun 2012

Jumlah karyawan berjenis kelamin laki-laki lebih banyak dibandingkan karyawan perempuan. Meskipun begitu, PT Jamsostek harus mulai mengantisipasi bahwa kondisi bahwa saat ini pengakuan terhadap pekerja wanita dan peningkatan partisipasi angkatan kerja wanita telah merubah komposisi demografis di tempat kerja. Macionis (1991) menyatakan bahwa karyawan laki-laki lebih dekat pada sifat ambisius dan kompetitif sehingga selalu mencari posisi kepemimpinan, sedangkan perempuan lebih bersifat diferensial dan emosional sehingga merupakan pendengar yang baik dan suportif terhadap yang lain. Kondisi tersebut tentu harus menjadi perhatian pemimpin dalam menerapkan gaya kepemimpinan untuk memotivasi munculnya kinerja yang tinggi.

Mayoritas karyawan PT Jamsostek Yogyakarta berumur 40 - 50 tahun. Conrad (2002) menyatakan bahwa individu harus bekerja pada usia produktif. Usia produktif adalah rentang usia manusia ketika umur mereka dapat dimanfaatkan untuk 
bekerja dan menghasilkan kontraprestasi atas hasil kerjanya. Sebelum orang mencapai usia produktif, mereka dikenal sebagai orang yang belum cukup keterampilan. Tetapi setelah orang melewati masa produktif, mereka dianggap sebagai orang yang terlalu tua untuk bekerja secara optimal. Di Indonesia kisaran usia produktif dari 18 - 55 tahun. Steers \& Porter (1981) (dalam Soeroso \& Sarwono (2001)) berpendapat bahwa secara kejiwaan pekerja yang lebih tua atau dewasa akan memiliki kematangan, ketenangan dan ketekunan dalam bekerja sehingga umur dapat dijadikan prediktor kinerja yang kuat.

Tabel 1 juga menunjukkan bahwa mayoritas masa kerja karyawan adalah antara 10 - 20 tahun, artinya telah cukup lama dalam menjalankan profesinya. Dengan pengalaman yang cukup ini karyawan diharapkan akan memahami misi, visi dan motivasi yang dapat meningkatkan kinerja karyawan.

\section{Analisis Diskripsi Variabel Penelitian}

Interval untuk item pertanyaan positif dan negatif diperoleh sebesar 0,75 dengan distribusi sebagai mana ditunjukkan pada Tabel 2.
Tabel 2: Interval

\begin{tabular}{|c|c|}
\hline Score Interval & Definisi \\
\hline $1,00-1,75$ & Sangat Tidak Baik/Sangat Rendah \\
\hline $1,751-2,5$ & Tidak Baik/Rendah \\
\hline $2,51-3,252$ & Baik/Tinggi \\
\hline $3,253-4,003$ & Sangat Baik/Sangat Tinggi \\
\hline
\end{tabular}

Sumber: Data Primer Yang Diolah Tahun 2012

\section{Analisis Deskriptif Variabel Gaya Kepe- mimpinan instruktif $\left(X_{1}\right)$}

Pada Tabel 3 ditınjukkan bahwa gaya kepemimpinan instruktif diterapkan secara baik oleh pimpinan di PT. Jamsostek Yogyakarta. Dalam gaya kepemimpinan instruktif ini seorang pemimpin cenderung memberikan pengarahan dan dukungan yang rendah. Pimpinan memberikan instruksi disertai pengawasan yang ketat sehingga gaya kepemimpinan ini sesuai untuk menghadapi bawahan yang belum matang. Tabel 3 juga menunjukkan bahwa karyawan PT. Jamsostek Yogyakarta memberikan penilaian yang rendah pada item atasan memberikan instruksi secara spesifik. Oleh karena itu, pimpinan pada PT. Jamsostek Yogyakarta dalam memberikan tugas atau pekerjaan kepada bawahan hendaknya disertai informasi yang jelas tentang dalam menyelesaikan pekerjaan tersebut, sehingga karyawan memiliki gambaran pelaksanaan tugasnya.

Tabel 3: Deskripsi Variabel Gaya kepemimpinan instruktif $\left(X_{1}\right)$

\begin{tabular}{clcc}
\hline No & \multicolumn{1}{c}{ Pernyataan } & Rerata & Ket. \\
\hline 1 & Atasan memberikan pengarahan dengan jelas. & 2,66 & Baik \\
2 & Atasan memberikan instruksi secara spesifik & 2,13 & Tidak Baik \\
3 & Atasan sangat memperhatikan tugas bawahan & 2,84 & Baik \\
4 & Atasan mengawasi dengan ketat pelaksanaan tugas bawahan & 2,91 & Baik \\
& RERATA & 2,63 & Baik \\
\hline
\end{tabular}

Sumber: Data Primer Yang Diolah Tahun 2012

Analisis Deskriptif Variabel Gaya kepemimpinan Konsultatif $\left(\mathrm{X}_{2}\right)$

Tabel 4. Deskripsi Variabel Gaya kepemimpinan Konsultatif $\left(X_{2}\right)$

\begin{tabular}{clcc}
\hline No & \multicolumn{1}{c}{ Pernyataan } & Rerata & Ket. \\
\hline 1 & Atasan memberikan petunjuk dan pengarahan kepada karyawan & 2,69 & Baik \\
2 & Atasan sering berkonsultasi dengan bawahan dalam pengambilan keputusan & 2,91 & Baik \\
3 & Atasan terbuka untuk komunikasi dengan karyawan & 3,06 & Baik \\
4 & Atasan tidak pernah memberikan pengendalian kepada bawahan & 2,88 & Baik \\
\hline & RERATA & 2,88 & Baik \\
\hline
\end{tabular}

Sumber: Data Primer Yang Diolah Tahun 2012 
Berdasarkan Tabel 4 menunjukkan bahwa pimpinan PT. Jamsostek Yogyakarta telah menerapkan gaya kepemimpinan konsultatif dimana pimpinan sering memberikan petunjuk dan pengarahan kepada bawahan, sering berkomunikasi dengan bawahan dalam pengambilan keputusan, terbuka untuk melakukan komuniksai dengan bawahan, dan tidak pernah memberikan pengendalian kepada bawahannya. Kepemimpinan konsultatif adalah dimana pemimpin memberikan direktif dan suportif yang tinggi. Setiap keputusan memperhatikan masukan bawahan yang telah lebih matang.

\section{Analisis Deskriptif Variabel Gaya Kepemimpinan Partisipatif $\left(\mathrm{X}_{3}\right)$}

Tabel 5 menunjukkan bahwa pimpinan PT. Jamsostek Yogyakarta telah menerapkan gaya kepemimpinan partisipatif dengan baik. Hasibuan (2006) menyatakan bahwa kepemimpinan partisipatif adalah apabila dalam kepemimpinannya dilakukan dengan cara persuasif, menciptakan kerja- sama yang serasi, menumbuhkan loyalitas, dan partisipasi para bawahan. Pemimpin memotivasi para bawahan agar merasa ikut memiliki perusahaan. Pemimpin dengan gaya partisipatif akan mendorong kemampuan bawahan mengambil keputusan sehingga bawahan mau menerima tanggung jawab yang lebih besar.

\section{Analisis Deskriptif Variabel Gaya Kepemimpinan Delegatif $\left(X_{4}\right)$}

Tabel 6 menunjukkan bahwa gaya kepemimpinan delegatif telah diterapkan dengan baik oleh pimpinan PT. Jamsostek Yogyakarta. Hasibuan (2006) berpendapat bahwa kepemimpinan delegatif akan mendelegasikan wewenang kepada bawahan kepada bawahan dengan agak lengkap. Dengan demikian, bawahan dapat mengambil keputusan dan kebijaksanaan dengan bebas atau leluasa dalam melaksanakan pekerjakannya. Pemimpin tidak peduli cara bawahan mengambil keputusan dan mengerjakan pekerjaannya, sepenuhnya di serahkan kepada bawahan.

Tabel 5: Deskripsi Variabel Gaya kepemimpinan Partisipatif $\left(X_{3}\right)$

\begin{tabular}{clcc}
\hline No & \multicolumn{1}{c}{ Pertanyaan } & Rerata & Keterangan \\
\hline 1 & $\begin{array}{l}\text { Atasan selalu mengadakan kerjasama dengan bawahan dalam } \\
\text { memecahkan masalah }\end{array}$ & 2,88 & Baik \\
2 & $\begin{array}{l}\text { Atasan sering membina kerjasama dengan bawahan dalam } \\
\text { pengambilan keputusan }\end{array}$ & 2,78 & Baik \\
3 & $\begin{array}{l}\text { Atasan saling bergantian dengan bawahan dalam pemecahan } \\
\text { masalah dan pembuatan keputusan }\end{array}$ & 2,94 & Baik \\
4 & $\begin{array}{l}\text { Atasan memberikan support kepada bawahan dalam pemecahan } \\
\text { masalah dan perbuatan }\end{array}$ & 2,81 & Baik \\
\hline & RERATA & 2,85 & Baik \\
\hline
\end{tabular}

Sumber: Data Primer Yang Diolah Tahun 2012

Tabel 6: Deskripsi Variabel Gaya kepemimpinan Delegatif $\left(X_{4}\right)$

\begin{tabular}{|c|c|c|c|}
\hline No & Pertanyaan & Rerata & Keterangan \\
\hline 1 & $\begin{array}{l}\text { Atasan memberikan kontrol pelaksanaan dengan memberikan } \\
\text { tanggung jawab kepada bawahan }\end{array}$ & 2,81 & Baik \\
\hline 2 & $\begin{array}{l}\text { Atasan memberikan kepercayaan penuh kepada bawahan untuk } \\
\text { menyelesaikan tugas tertentu }\end{array}$ & 2,78 & $\begin{array}{l}\text { Sangat } \\
\text { Baik }\end{array}$ \\
\hline 3 & Atasan memberikan kepercayaan kepada bawahan & 3,00 & Baik \\
\hline 4 & $\begin{array}{l}\text { Atasan memberikan kewenangan kepada bawahan untuk } \\
\text { memutuskan bagaimana cara melaksanakan tugas }\end{array}$ & 3,19 & Baik \\
\hline & RERATA & 2,95 & Baik \\
\hline
\end{tabular}

Sumber: Data Primer Yang Diolah Tahun 2012 


\section{Analisis Deskriptif Variabel Motivasi (Z)}

Tabel 7: Deskripsi Variabel Motivasi (Z)

\begin{tabular}{clcc}
\hline No & \multicolumn{1}{c}{ Pertanyaan } & Rerata & Keterangan \\
\hline 1 & Berusaha keras untuk mencapai prestasi kerja & 2,63 & Tinggi \\
2 & Menikmasti tantangan kerja yang sulit & 3,13 & Tinggi \\
3 & Karyawan dapat meningkatkan diri menyelesaikan setiap tugas & 2,97 & Tinggi \\
4 & Menikmati mencapai tujuan hidup yang realistis & 3,19 & Tinggi \\
5 & Puas apabila mampu menyelesaikan tugas-tugas & 3,09 & Tinggi \\
6 & Ingin bekerja dengan banyak orang & 3,06 & Tinggi \\
7 & Cenderung membanguan kerjasama dengan sesame teman kerja & 3,06 & Tinggi \\
8 & Senang bekerja dengan orang lain dari pada bekerja sendiri & 3,44 & Sangat Tinggi \\
9 & Menikmati setiap persaingan dan kemenangan & 2,75 & Tinggi \\
10 & Menikmati setiap tugas & 2,97 & Tinggi \\
\hline & RERATA & 3,03 & Tinggi \\
\hline
\end{tabular}

Sumber: Data Primer Yang Diolah Tahun 2012

Tabel 7 menunjukkan bahwa motivasi kerja pegawai PT. Jamsostek Cabang Yogyakarta termasuk tinggi, di mana motivasi tertinggi terjadi pada menikmati kerja lebih banyak dengan orang lain dari pada bekerja sendiri dan penilaian terendah adalah berusaha keras untuk mencapai prestasi kerja. Untuk meningkatkan semangat bekerja keras dapat dilakukan dengan meningkatkan tanggung jawab, pengakuan atas hasil kerja, insentif, kondisi kerja yang nyaman dan harmonisasi hubungan antar pribadi karyawan. Nawawi (2008) berpendapat bahwa setiap pekerja memerlukan motivasi yang kuat agar bersedia melaksanakan pekerjaannya secara bersemangat, bergairah dan berdedikasi. Motivasi kerja karyawan akan berpengaruh terhadap kinerja karyawan.

\section{Analisis Deskriptif Variabel Kinerja (Y)}

Tabel 8 menunjukkan bahwa kinerja karyawan secara rata-rata adalah sangat tinggi, di mana kinerja karyawan tertinggi terjadi pada monitoring bunga deposito dan penilaian terendah adalah penyerahan laporan keuangan $\mathrm{KBC}$.

\section{Analisis Statistik}

Gaya kepemimpinan instruktif, konsultatif, partisipatif, dan delegatif berpengaruh secara parsial dan simultan terhadap motivasi kerja karyawan PT. Jamsostek (Persero) di Yogyakarta.

$$
\begin{aligned}
Z= & 0,858+0,478 X_{1}+0,214 X_{2}+0,379 X_{3} \\
& +0,249 X_{4}
\end{aligned}
$$

Tabel 8: Deskripsi Variabel Kinerja $(Y)$

\begin{tabular}{clcc}
\hline No & \multicolumn{1}{c}{ Pertanyaan } & Rerata & Keterangan \\
\hline 1 & Tepat waktu penyerahan laporan keuangan & 3,66 & Sangat Tinggi \\
2 & Kualitas pengelolaan keuangan & 3,53 & Sangat Tinggi \\
3 & Koreksi & 3,66 & Sangat Tinggi \\
4 & Penyelesaian rekonsiliasi & 3,63 & Sangat Tinggi \\
5 & Penyerahan laporan keuangan KBC & 3,41 & Sangat Tinggi \\
6 & Penyerahan laporan keuangan DPKP & 3,53 & Sangat Tinggi \\
7 & Penyerahan laporan transaksi & 3,47 & Sangat Tinggi \\
8 & Sarana pendukung & 3,63 & Sangat Tinggi \\
9 & Pemenuhan erayfer pihak ke3 & 3,69 & Sangat Tinggi \\
10 & Monitoring bunga deposito & 3,72 & Sangat Tinggi \\
& RERATA & 3,59 & Sangat Tinggi \\
\hline
\end{tabular}

Sumber: Data Primer Yang Diolah Tahun 2012 
Tabel 9: Hasil Regresi

\begin{tabular}{|c|c|c|c|c|c|c|c|c|}
\hline Model & $\begin{array}{c}\text { Variabel } \\
\text { Independen }\end{array}$ & $\begin{array}{c}\text { Koef. } \\
\text { Regresi }\end{array}$ & $\begin{array}{c}\text { Koef. Beta } \\
\text { (Standardized) }\end{array}$ & Uji-t & sig & $\begin{array}{l}\text { Adj. R } \\
\text { Square }\end{array}$ & Uji-F & Sig.F \\
\hline 1 & Konstanta & 0,858 & & & & 0,707 & 19,716 & 0,000 \\
\hline $\begin{array}{l}\text { Variabel } \\
\text { Dependen: }\end{array}$ & $X 1$ & 0,251 & 0,478 & 4,463 & 0,000 & & & \\
\hline Motivasi & $\begin{array}{l}X 2 \\
X 3 \\
X 4\end{array}$ & $\begin{array}{l}0,094 \\
0,246 \\
0,182\end{array}$ & $\begin{array}{l}0,214 \\
0,379 \\
0,249\end{array}$ & $\begin{array}{l}2,184 \\
3,477 \\
2,476\end{array}$ & $\begin{array}{l}0,038 \\
0,002 \\
0,020\end{array}$ & & & \\
\hline $\begin{array}{l}2 \\
\text { Variabel } \\
\text { Dependen: } \\
\text { Kinerja } \\
\text { Karyawan }\end{array}$ & $\begin{array}{c}\text { Konstanta } \\
\text { Z }\end{array}$ & $\begin{array}{l}0,265 \\
1,098\end{array}$ & 0,738 & 5,991 & 0,000 & 0,529 & 35,887 & 0,000 \\
\hline 3 & Konstanta & 0,020 & & & & 0,831 & 39,168 & 0,000 \\
\hline $\begin{array}{l}\text { Variabel } \\
\text { Dependen: }\end{array}$ & $X 1$ & 0,353 & 0,452 & 5,555 & 0,000 & & & \\
\hline $\begin{array}{l}\text { Kinerja } \\
\text { Karyawan }\end{array}$ & X2 & 0,314 & 0,479 & 6,436 & 0,000 & & & \\
\hline & $\begin{array}{l}X 3 \\
X 4\end{array}$ & $\begin{array}{l}0,229 \\
0,369\end{array}$ & $\begin{array}{l}0,237 \\
0,339\end{array}$ & $\begin{array}{l}2,861 \\
4,435\end{array}$ & $\begin{array}{l}0,008 \\
0,000\end{array}$ & & & \\
\hline
\end{tabular}

Sumber: Data primer diolah, 2012

Hasil koefisien determinasi sebesar 0,707, artinya $70,7 \%$ motivasi dapat dijelaskan oleh variabel gaya kepemimpinan instruktif, konnsultatif, partisipatif dan delegatif. Sedangkan sisanya sebesar 29,3\% dipengaruhi oleh variabel lain yang tidak dimasukkan dalam model penelitian.

Hasil uji $t$ menunjukkan bahwa variabel kepemimpinan instruktif, konsultatif, partisipatif dan delegatif secara parsial mempunyai pengaruh positif dan signifikan terhadap motivasi. Hal ini ditunjukkan pada tabel 9 di mana probabilititas (sig-t) keempat variabel <0,05. Sedangkan hasil uji $F$ diperoleh nilai $F_{\text {hitung }}$ sebesar 19,716 dan probabilitas (Sig-F) sebesar $0,000<0,05$. Hasil uji $t$ dan uji $F$ tersebut menunjukkan bahwa hipotesis pertama yaitu "Gaya kepemimpinan instruktif, konsultatif, partisipatif, dan delegatif berpengaruh secara parsial dan simultan terhadap motivasi kerja karyawan PT. Jamsostek (Persero) di Yogyakarta" diterima. Hasil penelitian ini sesuai dengan pendapat Gitosudarmo (1997), yang menyatakan bahwa kepemimpinan sebagai suatu proses mempengaruhi aktivitas dari individu kelompok untuk mencapai tujuan dalam situasi tertentu.
Peranan kepemimpinan yang baik juga dapat berpengaruh besar pada karyawan, karyawan mendapatkan pengarahan dari pemimpin. Seorang pemimpin yang bertanggung jawab memberikan motivasi kerja bagi karyawan. Setiap pemimpin dalam suatu perusahaan, dengan gaya kepemimpinan yang tepat akan dapat memelihara kinerja karyawan dengan meningkatkan motivasi bawahan untuk dapat melaksanakan tugas mereka sesuai aturan dan pengarahan.

Gaya kepemimpinan instruktif, konsultatif, partisipatif, dan delegatif berpengaruh secara parsial dan simultan terhadap kinerja karyawan PT. Jamsostek (Persero) di Yogyakarta.

$$
\begin{aligned}
Y= & 0,020+0,452 X_{1}+0,479 X_{2}+0,237 X_{3}+ \\
& 0,339 X_{4}
\end{aligned}
$$

Hasil koefisien determinasi sebesar 0,831, artinya $83,1 \%$ kinerja dapat dijelaskan oleh variabel kepemimpinan instruktif, konsultatif, partisipatif dan delegatif. Sedangkan sisanya sebesar 16,9 persen dipengaruhi oleh variabel lain yang tidak dimasukkan dalam model penelitian.

Hasil uji $t$ menunjukkan bahwa variabel kepemimpinan instruktif, kepe- 
mimpinan konsultatif, kepemimpinan partisipatif dan kepemimpinan delegatif secara parsial mempunyai pengaruh positif dan signifikan terhadap kinerja. Hal ini ditunjukkan pada tabel 9 di mana dan probabilititas (sig-t) keempat variabel $<0,05$. Sedangkan hasil uji F yaitu diperoleh nilai $\mathrm{F}$ hitung sebesar 39,168 dan probabilitas (Sig-F) sebesar 0,000 0,05. Hasil uji $t$ dan uji $F$ tersebut menunjukkan bahwa hipotesis pertama yaitu "Gaya kepemimpinan instruktif, konsultatif, partisipatif, dan delegatif berpengaruh secara parsial dan simultan serentak terhadap kinerja karyawan PT. Jamsostek (Persero) di Yogyakarta" diterima. Hasil penelitian ini sesuai dengan pendapat Purnomo (2002), yang menyimpulkan bahwa kepemimpinan berpengaruh signifikan terhadap kinerja karyawan. Hasil penelitian juga sejalan dengan hasil penelitian Suranta (2003), Guritno \& Waridin (2005) dan Suharto dan Cahyono (2005) yang menunjukkan hasil bahwa ada pengaruh signifikan antara persepsi bawahan tentang gaya kepemimpinan terhadap kinerja bawahan.

Gaya kepemimpinan konsultatif mempunyai pengaruh paling besar terhadap kinerja karyawan PT. Jamsostek (Persero) di Yogyakarta.

$$
\begin{aligned}
Y= & 0,020+0,452 X_{1}+0,479 X_{2}+0,237 X_{3} \\
& +0,339 X_{4}
\end{aligned}
$$

Hasil regresi di atas, menunjukkan bahwa hipotesis ketiga yaitu "Gaya kepemimpinan konsultatif mempunyai pengaruh paling besar terhadap kinerja karyawan PT. Jamsostek (Persero) di Yogyakarta" diterima. Hasil penelitian ini tidak sesuai dengan penelitian yang dilakukan oleh Kim (2002), bahwa praktek manajemen partisipatif mempunyai pengaruh positif yang substansial terhadap kinerja dan kepuasan dalam pekerjaan. Hal ini dapat disebabkan oleh karakteristik responden, di mana dalam penelitian Kim, respondennya adalah importir di negara maju. Sedangkan dalam penelitian ini, respondennya adalah karyawan biasa.

Motivasi Kerja berpengaruh terhadap Kinerja karyawan PT. Jamsostek (Persero) di Yogyakarta.

$Y=0,265+0,738 Z$

Hasil koefisien determinasi sebesar 0,529 artinya 52,9\% kinerja karyawan dapat dijelaskan oleh motivasi karyawan dan sisanya sebesar 47,1 persen dijelaskan oleh variabel lain yang tidak dimasukkan dalam model penelitian. Hasil pengujian regresi pada variabel motivasi diperoleh koefisien beta sebesar 0,738 dan probabilitas (sig-t) sebesar $0,000<0,05$. Hasil ini mendukung bahwa hipotesis ketiga yaitu "Motivasi Kerja berpengaruh terhadap Kinerja karyawan PT. Jamsostek (Persero) di Yogyakarta" diterima. Hasil penelitian ini sesuai dengan penelitian Wahyuddin dan Djumino (2008) yang menemukan bahwa motivasi berpengaruh signifikan terhadap kinerja karyawan. Karyawan sebenarnya mempunyai motivasi kerja yang sangat beraneka ragam, bukan hanya motivasi kerja karena uang ataupun keinginan akan kepuasan, tetapi juga kebutuhan untuk berprestasi dan mempunyai "arti" dalam bekerja.

Pengaruh langsung (gaya kepemimpinan terhadap kinerja) lebih besar dibandingkan pengaruh tidak langsung (gaya kepemimpinan terhadap kinerja melalui motivasi kerja).

Penjelasan pengaruh langsung dan tidak langsung menjadi penting dalam analisis jalur guna mengetahui pengaruh total masing-masing variabel, ditunjukkan pada Tabel 10. Sarwono (2007) memberi contoh untuk penghitungan pengaruh tidak langsung adalah sebagai berikut. 1) Pengaruh gaya kepemimpinan konsultatif terhadap motivasi 0,214. 2) Pengaruh motivasi kerja terhadap Kinerja 0,738. 3) Pengaruh tidak langsung (Pengaruh gaya kepemimpinan konsultatif terhadap kinerja melalui motivasi: $0,214 \times 0,738=0,158$. 


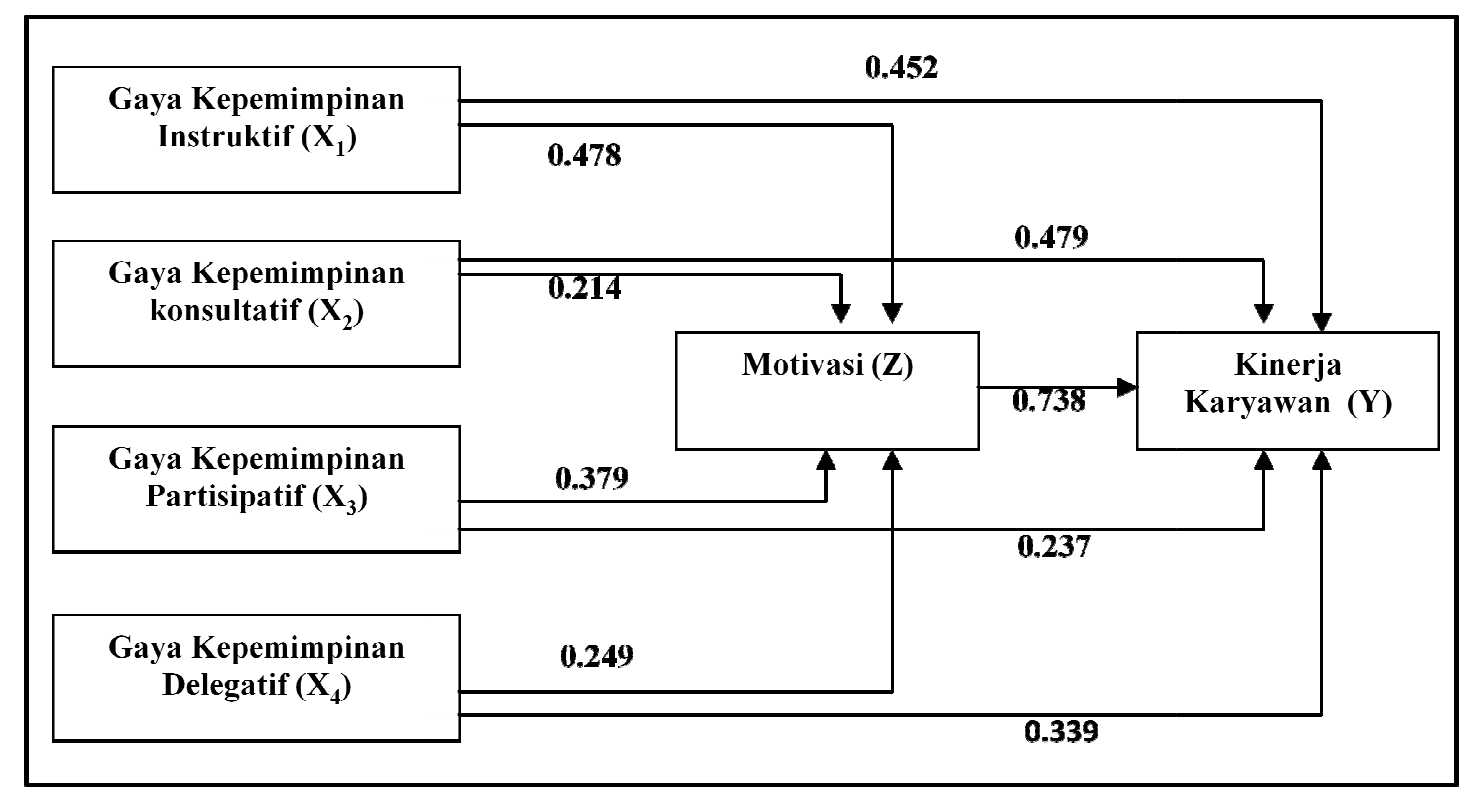

Gambar 2: Jalur Pengaruh Gaya Kepemimpinan Terhadap Kinerja Melalui Motivasi

Tabel 10: Pengaruh Langsung dan Tidak Langsung Dari Variabel Penelitian

\begin{tabular}{lccc}
\hline \multicolumn{1}{c}{ Variabel } & \multicolumn{2}{c}{ Pengaruh Langsung } & \multirow{2}{*}{ Pengaruh Tidak Langsung } \\
\cline { 2 - 4 } & Motivasi & Kinerja & \\
\hline Gaya Kepemimpinan Instruktif $\left(X_{1}\right)$ & 0,478 & 0,452 & 0,353 \\
Gaya Kepemimpinan konsultatif $\left(X_{2}\right)$ & 0,214 & 0,479 & 0,158 \\
Gaya Kepemimpinan Partisipatif $\left(X_{3}\right)$ & 0,379 & 0,237 & 0,279 \\
Gaya Kepemimpinan Delegatif $\left(X_{4}\right)$ & 0,249 & 0,339 & 0,184 \\
Motivasi $(Z)$ & & 0,738 & \\
\hline
\end{tabular}

Sumber; Data primer diolah, 2012

Besarnya pengaruh langsung gaya kepemimpinan instruktif $\left(X_{1}\right)$, konsultatif $\left(X_{2}\right)$ dan delegatif $\left(X_{4}\right)$ terhadap kinerja menunjukkan nilai yang lebih besar dibandingkan pengaruh tidak langsungnya. Hal ini menunjukkan untuk ketiga gaya tersebut, motivasi hanya menjadi variable intervening semu bagi terciptanya kinerja karyawan. Sedangkan untuk gaya kepemimpinan partisipatif menunjukkan pengaruh langsung lebih kecil dibandingkan dengan pengaruh tidak langsung. Hal ini menunjukkan bahwa variabel motivasi menjadi variabel intervening yang kuat bagi terciptanya kinerja. Hasil tersbut mendukung bahwa hipotesis kelima yaitu "Pengaruh langsung (gaya kepemimpinan terhadap kinerja) lebih besar dibandingkan pengaruh tidak langsung (gaya kepemimpinan terhadap kinerja melalui motivasi kerja)" terbukti.

\section{PENUTUP} Simpulan

1) Gaya kepemimpinan instruktif, konsultatif, partisipatif, dan delegatif berpengaruh secara parsial dan simultan terhadap motivasi kerja karyawan PT. Jamsostek (Persero) di Yogyakarta. 2) Gaya kepemimpinan instruktif, konsultatif, partisipatif, dan delegatif berpengaruh secara parsial dan simultan terhadap kinerja kerja karyawan PT. Jamsostek (Persero) di Yogyakarta. 3) Gaya kepemimpinan konsultatif mempunyai pengaruh paling besar terhadap kinerja karyawan PT. Jamsostek (Persero) di Yogyakarta. 4) Motivasi Kerja berpengaruh terhadap Kinerja karyawan PT. Jamsostek (Persero) di Yogyakarta. 5)Pengaruh langsung (gaya kepemimpinan terhadap kinerja) lebih besar dibandingkan pengaruh tidak langsung (gaya kepemim- 
pinan terhadap kinerja melalui motivasi kerja).

\section{Saran}

1. Pimpinan PT. Jamsostek Cabang Yogyakarta hendaknya meningkatkan penerapan gaya kepemimpinan instruktif dan gaya kepemimpinan konsultatif karena memiliki pengaruh paling besar terhadap motivasi dan kinerja karyawan. Pimpinan sebaiknya melakukan empat hal berikut. (1) Memberikan gambaran yang jelas tentang pelaksanaan tugas dan kewenangan kepada bawahan. (2) Memantau bawahan. (3) Bersedia mendengar- kan usulan dan keluhan yang dirasakan oleh bawahan. (4) Mengadakan kerjasama dengan bawahan dalam memecahkan masalah.

2. Motivasi kerja terbukti berpengaruh terhadap kinerja karyawan. Perhatian pemimpin sangat penting untuk dapat memelihara motivasi kerja karyawan. Dampak peningkatan kinerja karyawan dapat melalui lima faktor, (1) pemberian tanggung jawab yang lebih tinggi, (2) peningkatan pengakuan atas hasil kerja, (3) peningkatan insentif, (4) menciptakan kondisi kerja yang nyaman, dan (5) harmonisasi hubungan antar pribadi karyawan.

\section{DAFTAR PUSTAKA}

Conrad, A., (2002), “The Influence Of Social Interaction On Knowledge Creation”, Journal of Intelectual Capital, 3(4), pp. 1-16.

Gitosudarmo, Indriyo dan Sudita, I Nyoman, (1997), Perilaku Organisasi, Edisi Pertama, BPFE, Yogyakarta.

Guritno, Bambang \& Waridin, (2005), “Pengaruh Persepsi Karyawan Mengenai Perilaku Kepemimpinan, Kepuasan Kerja dan Motivasi Terhadap Kinerja", Jurnal Riset Bisnis Indonesia, Vol 1 No. 1, hal. 63-74.

Handoko, T. Hani, (2011), Manajemen Personalia dan Sumber Daya Manusia, BPFE, Yogyakarta.

Hasibuan S.P Malayu, (2006), Manajemen Sumber Daya Manusia, PT. Bumi Aksara, Jakarta.

Kim, Soon Hee, (2002), "Participative Management and Job Satisfaction: Lesson for Management Leadership", Public Administration Review, Vol 62, No.2, pp. 231-241.

Macionis, J.J. (1991), Sociology, 3rd ed., Englewood Cliffs, NJ, USA: Prentice Hall, Inc.

McClelland, David C., (1961), The Achieving Society. D. Van Nostrand Company, Inc, USA.

Mehta, R., Dubinsky, A.J., \& Anderson, R.E, (2003), “Leadership Style, Motivation and Performance in International Marketing Channel: An Empirical Investigation of USA, Finland and Poland", European Journal of Marketing, 37 (1/2), pp. 50-86.

Nawawi, Hadari, (2008), Riset Sumber Daya Manusia Untuk Bisnis Yang Kompetitif, UGM, Yogyakarta.

Notoatmodjo, Soekidjo (2003), Metodologi Penelitian Kesehatan. Jakarta: PT Rineka.

Payamta, (2005), “Gaya Kepemimpinan: Perkembangan dan Kepemimpinan Dalam Era Global", Telaah, Volume 2 Nomor 1, AMP YKPN, pp. 11-2.

Pfeffer, Jeffrey, (1997), New Directions for Organization Theory: Problems and Prospects. Oxford University Press, USA. 
Popenoe, D., (1977), Sociology, 3rd ed., Prentice Hall, Inc., Englewood Cliffs, New Jersey, USA.

Prawirosentono, Suyadi., (1999), Kebijakan Kinerja Karyawan, Yogyakarta: BPFE.

Purnomo, Joko, (2002), "Pengaruh Kepemimpinan, Motivasi, Dan Lingkungan Kerja Terhadap Kinerja Pegawai Negeri Sipil Pada Dinas Kehutanan Dan Perkebunan Kabupaten Jepara", Daya Saing: Jurnal Ekonomi dan Manajemen Bisnis, Universitas Muhammadiyah Surakarta, Surakarta, Jawa Tengah.

Robbins P Stephen, (2006), Perilaku Organisasi, Jilid 1, PT. Indeks Kelompok Gramedia.

Sarwono, Jonathan, (2007), Analisis Jalur Untuk Riset Bisnis dengan SPSS, Penerbit Andi, Yogyakarta.

Sarwono, Slamet S., dan Soeroso, Amiluhur, (2001), “Determinasi Demografi Terhadap Perilaku Karitatif Keorganisasian", Jurnal Siasat Bisnis, No. 6 Vol 1, Jurusan Manajemen, Fakultas Ekonomi Universitas Islam Indonesia, Yogyakarta.

Shea Christine M, (1999), “The Effect of Leadership Style on Performance Improvement on a Manufacturing Task", Journal of Business, Vol 72, No. 3.

Steers, R.M., and L.W. Porter., (1991), Motivation and Work Behavior, 5th ed., McGraw-Hill, Inc., New York, USA.

Suharto \& Cahyono Budi, (2005), "Pengaruh Budaya Organisasi, Kepemimpinan dan Motivasi Kerja Terhadap Kinerja Sumber Daya Manusia di Sekretariat DPRD Propinsi Jawa Tengah", Jurnal Riset Bisnis Indonesia, Vol 1 No. 1, 13-30, Universitas Islam Sultan Agung, Semarang.

Suprihanto, John, dkk, (2003), Penilaian Kinerja dan Pengembangan Karyawan, Edisi Pertama, BPFE, Yogyakarta.

Suranta, Sri (2003), "Pengaruh Gaya Kepemimpinan Terhadap Kinerja Karyawan Perusahaan Bisnis dengan Motivasi Karyawan Sebagai Variabel Pemoderasi", Perspektif Vol 8 No.1, 73 -88, Fakultas Ekonomi UNS, Surakarta.

Wahyuddin, M., dan Djumino, A, (2006), “Analisis Kepemimpinan dan Motivasi Terhadap Kenerja Pegawai Pada Kantor Kesatuan Bangsa dan Perlindungan Masyarakat Di Kabupaten Wonogiri", Jurnal BENEFIT, Vol. 1 No. 2 Universitas Muhammadiyah Surakarta, Surakarta. 